\title{
COLLECTIVE RISK MODEL IN NON-LIFE INSURANCE
}

\author{
Zlata Djuric* \\ Faculty of Economics, University of Kragujevac, Kragujevac, Serbia
}

\begin{abstract}
The operation of business insurance companies, based on assuming risks of different profiles, is accompanied by fluctuations in the business environment. The complexity of predicting a financial effect for claims in non-life insurance lies in the structure of insurers' liabilities, whose amount cannot be determined at the time of payment of the premium. By analyzing the key insurance processes, risk theory focuses on modeling claims as the financial consequences of unforeseen events. In addition, it provides the answer as to how much of a premium to charge in order to avoid bankruptcy, which makes it a complex and topical research area. The paper presents the main results of the collective risk model for the key business processes of nonlife insurance companies: the claim number process and the claim amount process. In risk theory, these are treated as stochastic processes, which offers a wide range of possibilities for the modeling and simulation of specific business problems.
\end{abstract}

Keywords: non-life insurance, risk theory, stochastic process, Poisson process, premium calculation principles

\section{JEL Classification: C13, C43, C46}

\section{INTRODUCTION}

Risk avoidance has generated the establishment and operation of insurance companies which provide their clients with opportunities to disperse and minimize their losses. The insured transfer their risks to insurers who, by forming a large enough group of related risks, reduce the loss of each insured by charging an appropriate premium. The basic source of all non-life insurers' dilemmas lies in the fact that the premiums are paid prior to the occurrence of any adverse events. It is therefore necessary to assess

\footnotetext{
* Correspondence to: Z. Djuric, Faculty of Economics, University of Kragujevac, Dj. Pucara 3, 34000 Kragujevac, Serbia; e-mail: zdjuric@kg.ac.rs
}

the likelihood of realization, as well as the monetary value of the loss that must be compensated for. The theory of probability and statistics allows insurers to see unfortunate events as phenomena that, because of certain regularities, can be predicted and modeled (Embrechts \& Klüppelberg, 1993). The application of the risk theory in non-life insurance is an even more powerful tool for analyzing and defining very complex business risks. The acceptance of a variety of risks has framed three basic questions that non-life actuaries, above all others, must focus their attention on in order to adequately protect their customers:

- How much of accepted risks can be realized in a specific time, or how many compensation requests can be expected on the basis of the collected insurance policies? 
- What amount of money should be provided for the payment of claims received, i.e. what is the average expected amount of a claim?

- How much of a premium to charge to the insured in order to absorb the claim and provide income to insurance companies?

The application of the risk theory in general insurance is accompanied by criticisms of its limited practical importance in the business world, so that it has long been ignored and theoretically and mathematically developed mainly by Scandinavian scientists. Today, however, it is a major research challenge for many mathematicians and actuaries due to the broad framework and the logical context within which it is possible to simulate natural fluctuations present in real business processes. Solvency II, a new updated set of regulatory requirements for insurance companies operating in the European Union, requires the complete treatment and measurement of a risk-margin based on risk, which has promoted the application of the risk theory. Apart from the traditional methods, there is now a need for a new dynamic approach based on the stochastic concept of the realization of adverse events.

Insurers are generally interested in total payments that may follow from the insurance portfolio. If the present value of the total potential payout is seen as the sum of individual payments, we are talking about the individual risk model. The second model, which observes the aggregate amount of claims arising from all of the collected policies, is known as the collective risk model. Although more recent, it has significantly outperformed the older, individual, model because of its applicability.

This paper analyzes the modeling of the key processes in the operation of insurance companies: the claim number process and the claim amount process. The aim of this paper is to present the advantages and disadvantages of the collective risk theory in the analysis of this problem, pointing out the possibility of their application and directions for further development. Therefore, the key hypothesis considered in the paper is: the risk theory, although not very applicable in practical work, provides a broad framework for monitoring, analyzing and predicting a number of high-risk situations and provides guidance for mitigating and overcoming the problems that may arise.

Starting from the defined object and purpose, the paper will first present the general model of the risk theory in general insurance, and then analyze the application of Poisson process and its modification in the claim number process. The integration of this processes with the process of the total amount of paid claims makes the research area very complex, but predominant when setting up the basic principles of quantifying the premium.

\section{COLLECTIVE RISK MODEL}

Mathematical models in the theory of non-life insurance analyze claims for damages to provide an answer as to how much premium to charge in order to avoid bankruptcy. Claims incoming to an insurance company can be treated as random variables reflecting the collection of the adverse outcomes realization of insured events (claims) on a set of real numbers (the monetary payoff amount) or as mapping $X: \Omega \rightarrow R$, where $\Omega$ is the set of elementary events and $\mathrm{R}$ is the set of real numbers. The manner and probability of the occurrence of claims or monetary payments represents the probability distribution of these random variables. Every random variable may be associated the distribution function, $F_{X}$ to, which does not describe the actual outcome of the random variable $X$, but rather tells us how the possible values of $X$ are distributed. Function $F_{X}(x): R \rightarrow[0,1]$, defined with

$F_{X}(x)=P(\omega \in \Omega \mid X(\omega) \leq x)=P(X \leq x)$, for $x \in R$, is the distribution function of random variable $X$ and represents a probability that random variable $X$ should take values less than or equal to $x$. In the context of insurance, if a random variable is the amount of the claim of an insured, the distribution function is a probability that the total amount of insured damage observed will be less than or equal to the fixed amount $x$. For a continuous random variable, the distribution function is $F_{X}(x)=P(X \leq x)=\int_{-\infty}^{x} g(x) d x, \quad x \in R$ where $g(x)$ is the probability density function. The most important numerical characteristics of random 
variables are obtained by using the expected value and variance. The expected value or expectation of a discrete random variable is $E(X)=\sum_{i=1}^{n} x_{i} \cdot p_{i}$, while the continuous random variable $E(X)=\int_{-\infty}^{+\infty} x g(x) d x$. The variance is often used as an indicator of the homogeneity of a population or a sample. For a discrete random variable, the variance is

$\operatorname{Var}(X)=\sigma^{2}=E(X-E(X))^{2}$, so it is a measure of the deviation of a random variable from its expected value. For a continuous random variable,

$$
\sigma^{2}=\int_{-\infty}^{+\infty}(x-E(X))^{2} \cdot g(x) d x
$$

The concept of a random variable is independent of time. However, many business processes are to be analyzed and their implementation monitored at random times, so it is necessary that the time component should be included. Random variable $X$, whose implementation is monitored in time, is denoted by $\mathrm{X}_{t}$ or $\mathrm{X}(\mathrm{t})$. If $T \subset R$ is a set of time, then $\mathrm{X}_{t}$ is determined for every a certain family of random variables, which defines the stochastic process. A stochastic process $X=\left\{X_{t}, t \in R\right\}$ can be treated as a function of two variables and defined as $X: \mathrm{T}^{\times} \Omega \rightarrow$ $K$, where $K$ is the set of states, a set containing all the values of the observed process. For a selected time $t \in T$ and an elementary event $\omega \in \Omega$, the realization of the process is denoted by $X(t, \omega)$. Therefore, if the time is fixed, then the function $\omega \rightarrow X(t, \omega)$ is the random variable describing the process of implementation in a future time $t$, whereas if the event is fixed $\omega \in \Omega$, then the function $t \rightarrow X(t, \omega)$ describes the implementation of the process $X$ over time. This time function is the realization or trajectory of the stochastic process. Moreover, if the set $\mathrm{T}$ is countable, there is a discrete random process or a series of random variables, otherwise there is a continuous process.

For a process to model, it is necessary that realistic assumptions faithfully describing the basic characteristics of this problem be introduced, as well as such that can mathematically be formulated while their characteristics and implications can easily be proved. "In the collective risk model, one starts from the following hypotheses (Ramasubramanian, 2005, 2):
1. The total number of claims, $B$, received at a time, is a random variable. Claims arrive at an insurance company in times $\{T i\}$, valid for $0 \leq T_{1} \leq T_{2} \leq \ldots$. , and they are claims arrival times;

2. Any claim, arrived in time Ti induces the payment of damages $X_{i}$, or an amount of the claim. Sequence $\left\{X_{i}\right\}$ is a sequence of nonnegative, independent identically distributed random variables (i.i.d. random variables);

3. The claim size process $\left\{X_{i}\right\}$ and the time of maturity $\left\{T_{i}\right\}$ are independent of each other. The process size and the claims number, $\left\{X_{i}\right\}$ and $B$, are also independent."

The two most important processes accompanying the process of business insurers are the claims number process and the total claim amount process. As both processes are followed in time, they are stochastic processes. In addition, the claims number process, i.e. the number of claims incurred, is defined:

$$
B(t)=\max \left\{i \geq 0: T_{i} \leq t\right\}
$$

and represents the number of claims received at time $t \geq 0$, while the process of the total amount of claims paid is

$$
Z(t)=X_{1}+\ldots .+X_{B(t)}=\sum_{i=1}^{B(t)} X_{i}, t \geq 0 .
$$

As the deterministic index $n$ of the partial sum $Z_{n}=X_{1}+X_{2}+\ldots+X_{n}$ is replaced with a random variable $B(t)$, the process $Z=(Z(t), t \geq 0)$ is a random process of partial sums, often referred to as the compounded or collective process.

\section{MODELING THE NUMBER OF CLAIMS}

The Poisson process, introduced in F. Lundberg (1903) as a model for the claim number process $\{B(t): t \geq 0\}$, where $B(t)$ is a random variable, has the central and dominant place in non-life insurance mathematics, in the collective risk theory in particular.

According to the classical definition of the probability theory, an integer random variable $Y$ is said to have a 
Poisson distribution if: $P(Y=k)=e^{-\lambda} \frac{\lambda^{k}}{k !}$, for $k \in\{0,1,2 \ldots\}$ and for $\lambda>0$. The Poisson random variable is used as a model for the number of phone calls per unit of time, the number of cars and buses that pass through a point per unit of time, the number of users who accessed a web site, the number of radioactive particles per unit of time, and so on. It has a very rare, but very useful property that $E(Y)=\operatorname{var}(Y)=\lambda$.

The Poisson process monitors the occurrence of an event over time and the moments in which the event occurred, so that it has widely been applied in the modeling of rare events or events for which there is no more than one possible realization in a short period of time. "The Poisson process is a random process, defined on a set of time, as a family of random variables $\{B(t)\}, t \in T$, where there is set $T=[0,+\infty)$, if the following is fulfilled (Ramasubramanian, 2005, 3):

(1) $B(t)$ is a non-negative integer random variable which is true $B(0) \equiv 0, \forall t \geq 0$, which means that there is no claim at time $t=0$;

(2) $\{B(t): t \geq 0\}$ is a non-decreasing process, i.e. if $0 \leq s<t$, then $B(t) \leq B(s)$, where $B(t)-B(s)$ denotes the number of claims received in the time interval $(\mathrm{s}, \mathrm{t}]$;

(3) $\{B(t): t \geq 0\}$ has independent increments such that for $0<t_{1}<t_{2}<\ldots<t_{n}<\infty$ number of claims received in the disjoint intervals $B\left(t_{1}\right)$, $B\left(t_{2}\right)-B\left(t_{1}\right), \ldots \ldots, B\left(t_{n}\right)-B\left(t_{n-1}\right)$, for $n=1,2, \ldots$ are independent random variables;

(4) a probability of the arrival of a certain number of claims at a time interval depends only on the length of the interval, so that the claim number process has stationary increments, i.e. for $0 \leq s<t$ and $h>$ 0 , independent random variables $B(t)-B(s)$ and $B(t+h)-B(s+h)$ have the same distribution;

(5) a probability of the arrival of two or more claims in a particular time interval is negligibly low, i.e. $P(B(h) \geq 2)=o(h)$, ie. $P(B(t+h)-B(t) \geq 2)$ $=o(h)$, where $o(h)$ is an infinitely small size with the property $\lim _{h \rightarrow 0} \frac{o(h)}{h}=0$;
(6) in a very short time, a probability of the arrival of a request is approximately proportional to the length of the interval, so there is a $\lambda>0$ such that $P(B(h)=1)=\lambda h+o(h)$, when $\rightarrow 0$. Number $\lambda$ is the claim arrival rate."

Although the Poisson process is not the most realistic process for the claim number process due to its many attractive and applicable properties developed and detected over several decades, it is a reference point in modeling. The limitation of the standard Poisson process can be reduced and the models expanded by various modifications of the standard Poisson process, analyzed in detail by J. F. C. Kingman (1993). Thus, for modeling the claims number process, there are two, much broader and more realistic, other processes that appear: the renewal process and the mixed Poisson process.

"For the formulation and mathematical modeling of the claims number process, we start from the following assumptions, which are both natural and necessary (Minkowa, 2010, 31):

- $B(t) \geq 0$

- $B(t)$ is the integer

- $0 \leq s<t$, then $B(t) \leq B(s)$,

- $B(t)-B(s)$, for $s<t$, is the number of claims received in the interval $(\mathrm{s}, \mathrm{t}]$."

The definition of the Poisson process implies that, for each stochastic process, which includes the claim number process, $\{B(t): t \geq 0\}$ for $s \geq 0, k=0,1,2, \ldots$ is valid:

$$
\begin{aligned}
& P(B(t+s)-B(s)=k)= \\
& =P(B(t)=k)=\frac{(\lambda t)^{k}}{k !} e^{-\lambda t}
\end{aligned}
$$

or the claim number process is a homogeneous Poisson process, with the rate of the arrival of claim $\lambda$, where $\lambda$ is a constant. The proof of this result and different approaches performing it can be found in the works of many authors, such as N. L. Bowers et al (1997), C. T. Daykin et al (1994), S. Klugman et al (1998).

For the claim number process, from the aspect of insurance, the time between the arrivals of two consecutive claims is also important. If the arrival time 
of the n-th claim or the waiting time of the n-th claim is defined by:

$$
T_{n}=\inf \{t \geq 0: B(t)=n\}, n=1,2, \ldots, T_{0}=0,
$$

it can be assigned a series of time between two successive claims $A_{i}$, defined by $A_{i}=T_{i}-T_{i-1}$. Analogously to these definitions, it follows

$$
\forall s:\left\{T_{1}>s\right\}=\{B(s)=0\}
$$

where

$P\left(A_{1}>s\right)=P(B(s)=0)=e^{-\lambda s}$

Inductively, it can be seen that, for the Poisson process $\{B(t): t \geq 0\}$ with a growth rate $\lambda$, the random variables $A_{i}$ are independent random variables, exponentially distributed, with parameter $\lambda$, ie $A_{i}: \varepsilon(\lambda)$, so that $E\left(A_{i}\right)=\frac{1}{\lambda}, \forall i, \lambda>0$.

As $T_{n}=A_{1}+A_{2}+\ldots+A_{n}$ is the sum of random variables with exponential distribution, it means that the arrival time of the n-th claim $T_{n}$ has a gamma distribution, $T_{n}: \Gamma(n, \lambda)$ (Rolski et al, 1999).

One of the key characteristics of Poisson processes $\{B(t): t \geq 0\}$ is that the time between the arrivals of two successive claims is a random variable with an exponential distribution with rate $\lambda$. Another important feature of the process $\{B(t): t \geq 0\}$ is that these times are independent. These two features provide us another way of generalizing the Poisson process. Specifically, we can assume that nonnegative, independent random variables $A_{i}$ with the same distribution can have whatever, either a discrete or an absolutely continuous distribution. This assumption leads us to the renewal process (Asmussen, 2000), which provides greater flexibility in choosing a time schedule for $A_{i}$. Unlike the Poisson process, where $B(t)$ has a Poisson distribution for each $t$, in the renewal process, this property does not apply, so the distribution for $B(t)$ is generally not known, and the determination of the probability of the event $B(t)=n$ is reduced to the determination of the expectation of the random variable $B(t)$ (Panjer \& Willmot, 1992).

Also, as for the arrival time of the $n$-th claims $T_{n}=\sum_{i=1}^{n} A_{i}$, it holds that:

$$
T_{n} \leq s \Leftrightarrow B(t)=n
$$

In general, it is difficult to determine the distribution for $T_{n}$ but we know that, if $A_{i}: \mathcal{E}(\lambda)$ then $T_{n}: \Gamma(n, \lambda)$ and if $A_{i}: \operatorname{Poi}(\lambda)$ then $T_{n}: \operatorname{Poi}(n, \lambda)$. Studies by many scientists in the field of the renewal process (Kling \& Goovaerts, 1993) have led to a powerful mathematical theory - the renewal theory, which allows you to very precisely determine the expected number of requests $E(B(t))$ for a large $t$. According to the strict law of large numbers, if the expectation of the time of the arrivals of two successive claims $\mathrm{E}\left(A_{i}\right)=\lambda^{-1}$ finally, then

$$
\lim _{t \rightarrow \infty} \frac{B(t)}{t}=\lambda
$$

Also, according to the elementary renewal theorem, the following applies:

$$
\lim _{t \rightarrow \infty} \frac{E(B(t))}{t}=\lambda
$$

The most accurate information about the pending arrival times of claims is given in Blackwell's renewal theorem, according to which

$$
E(B(t, t+h]) \rightarrow \lambda h, t \rightarrow \infty
$$

So, the expected number of renewals per interval $(t, t+h]$, for a sufficiently large $t$, is proportional to the length of the interval and independent of $t$.

The basic premise that the average rate of claim occurrence is constant is not realistic since the claim arrival is often dependent on the weather. Looking at the parameter $\lambda$ as a function of time $t$, the model of a homogeneous Poisson process can be extended to a non-homogeneous Poisson process. It also starts with a zero, has independent increments for which it is true that for $0 \leq s<t$, increment $B(t)-B(s)$ is Poisson distributed with the parameter $\int_{t}^{t} \lambda(y) d y$. Furthermore, unction $\mu(t)=\int_{0}^{t} \lambda(y) d y$ is a function of the mean value of a non-homogeneous Poisson process, for some non-negative measurable function $\lambda$. If the function of the mean value is linear, i.e. $\mu(t)=\lambda t$, it is a homogeneous Poisson process; otherwise it is a 
non-homogeneous one. By introducing the intensity function $\lambda(t)$, the arrival process can be monitored and modeled according to seasonal trends as well. If claims come from heterogeneous insured groups, the arrival claim rate varies from one policy to another, so that $\lambda(t)$ can be viewed as a random variable $\Lambda(t), \forall t>0$.

The set $\{\Lambda(t), t \geq 0\}$ is a stochastic process and therefore, the process $\{B(t): t \geq 0\}$ is a double stochastic Poisson process. Treating the $\lambda$ as a random variable independent of time, this stochastic process $\{B(t): t \geq 0\}$ is a mixed Poisson process, which is an even more powerful generalization of general Poisson processes. The mixed Poisson process loses some properties of the Poisson process (increments are mutually dependent, the distribution for $B(t)$ in general is not Poisson's), but it provides many more choices than the trajectories of the Poisson process and the renewal process (Grandell, 1997).

\section{MODELING THE TOTAL CLAIM AMOUNT PROCESS}

Analyzing the claims process is extended when the consideration includes not just the number of the claims received but the size of the claims demands induce, too. The sum of individual claims or the aggregate amount of the claims is a key problem, both in practice and in theoretical discussion. In fact, as the number of claims and the amount of the claim are stochastic variables, there is a double stochastic model of the aggregate amount of claims. Depending on the selection of the claim number process $B$, there are different models for the total claim amount process until the moment of time $t$ :

$Z(t)=X_{1}+\ldots .+X_{N(t)}=\sum_{i=1}^{B(t)} X_{i}, \mathrm{t} \geq 0$

"One of the most popular and useful models in non-life insurance mathematics is Cramer-Lundberg's model (Cramer, 1955), which combines the claim amount and the arrival time, with the following assumptions (Mikosch, 2009, 18):

- $\quad$ The claim number process $B(t)=\max \left\{i \geq 0: T_{i} \leq t\right\}$ is a homogeneous Poisson process with rate $\lambda>0$, in which claims are realized in arrival times $0 \leq T_{1} \leq T_{2} \leq \ldots$;

- The claim received at the time $T_{i}$ induces the payment of damage $X_{i}$. Sequence $\left\{T_{i}\right\}$ is a sequence of nonnegative, independent random variables with the same distribution function;

- Sequences $\left\{X_{i}\right\}$ and $\left\{T_{i}\right\}$ are mutually independent."

If we consider that the discounted sum i.e. the present value of the cumulative amount of claims in the time interval $[0, \mathrm{t}]$ :

$Z_{0}(t)=\sum_{i=1}^{B(t)} e^{-V_{i}} X_{i}, t \geq 0$

where $r>0$ is the interest rate, in Cramer-Lundberg's model, the expected amount necessary for settling the claims received in the observed time interval is

$E\left(\sum_{i=1}^{B(t)} e^{-r T_{i}} X_{i}\right)=\lambda \frac{1}{r}\left(1-e^{-r t}\right) E\left(X_{1}\right)$

Insurers are generally interested in the order of the magnitude of $Z(t)$, and consequently in the distribution functions for $Z(t)$. Since determining the distribution for $Z(t)$ is a very complicated problem, the solution lies in a simulation model and in obtaining rough estimates of the mean and the variance of $Z(t)$.

The expectation of the total amount of paid claims indicates its average size. Assuming independence between $X_{i}$ and $B$, if $E(B(t))$ and $E\left(X_{1}\right)$ are final, it can easily be obtained that:

$$
\begin{aligned}
& E(Z(t))=E\left[E\left(\sum_{i=1}^{B(t)} X_{i} \mid B(t)\right)\right]= \\
& =E\left(B(t) E X_{1}\right)=E(B(t)) E\left(X_{1}\right)
\end{aligned}
$$

As in Cramer-Lundberg's model the process $B(t)$ is a homogeneous Poisson process, then $E(B(t))=\lambda t$, where $\lambda$ is the intensity rate of a homogeneous Poisson process, so that from (14) we obtain:

$E(Z(t))=\lambda t E\left(X_{1}\right)$

To have more complete information about the distribution of $Z(t)$, we should combine information about the expectation with the variance $\operatorname{Var}(Z(t))$, for which the following is valid (Mikosch, 2004): 


$$
\begin{aligned}
\operatorname{Var}(Z(t)) & =E(B(t)) \operatorname{Var}\left(X_{1}\right)+ \\
& +\operatorname{Var}(B(t))\left(E\left(X_{1}\right)\right)^{2}
\end{aligned}
$$

As in Cramer-Lundberg's model it holds that $E(B(t))=\operatorname{Var}(B(t))=\lambda t$, we obtain:

$\operatorname{Var}(Z(t))=\lambda t E\left(X_{1}^{2}\right)$

Yet another important model for the process $\{Z(t): t$ $\geq 0\}$ was introduced by Sparre-Andersen (Andersen, 1957) and its implications have been studied by many authors (Sharif \& Panjer, 1995; Genest et al, 2003), for whom the process $\{B(t): t \geq 0\}$ is a renewal process. In the renewal model, however, the determination of the estimates of expectations and variances is difficult and does not give such concrete results. We have seen that, according to the strict law of large numbers, if the expectation of the arrival times of two consecutive $\underset{t \rightarrow \infty \text {. claims }}{ } E\left(A_{i}\right)=\lambda^{-1}<\infty$, then $\frac{E(B(t))}{t} \rightarrow \lambda$, when

$E(Z(t))=\lambda t E\left(X_{1}\right)(1+o(1)), t \rightarrow \infty$

and

$$
\begin{aligned}
\operatorname{Var}(Z(t)) & =\lambda t\left[\operatorname{Var}\left(X_{1}\right)+\operatorname{Var}\left(A_{1}\right) .\right. \\
& \left.\cdot \lambda^{2}\left(E\left(X_{1}\right)\right)^{2}\right](1+o(1))
\end{aligned}
$$

Based on these results, we find that the expectation and variance asymptotically grow almost linearly as a function of time $t$. This information can be very useful in the practical determination of premiums sufficient for the settlement of losses, the size of $Z(t)$.

\section{PREMIUM CALCULATION PRINCIPLES}

The amount of the money the insured pays the insurer, as a compensation for risk, is a premium. Risks and a premium are closely related to each other since a premium amount is determined by an average size of a risk, whose every change must be reflected in the amount of such a premium. Looking at a premium as a monetary payment from the insurer, in the context of the above processes, it is obvious that an insurance company will be operating at a loss if a premium is less than the expected amount of payments i.e. if
$p(t)<Z(t)$. As we have obtained in previous arguments that $E(Z(t))=\lambda t E\left(X_{1}\right)(1+o(1))$, $t \rightarrow \infty$, it is logical to determine a premium so that:

$p(t)=\lambda t E\left(X_{1}\right)(1+\rho)$

where $\rho$ is a positive constant and represents safety loading or a charge for security.

In the risk theory, there are principles which all premiums $p(t)$ should satisfy, known as the premium principles. To determine a premium, as the mapping of uncertain future losses onto their financial equivalent, actuaries have developed a number of methods for the determination of the premium principles (Albers, 1999; Dickson, 1991; Landsman et al, 2001), the following ones being basic:

- The principle of net premium is a basic principle, according to which $p(t)=E(Z(t))$. It does not include safety loading, because actuaries often assume that there is practically no risk if the insurer sells enough of identically distributed and independent policies;

- The principle of the expected value is based on the previous one, but incorporates proportional safety loading. According to this principle, $p(t)=(1+\rho)$ $E(Z(t))$ for some $\rho>0$. This principle is generally used in life insurance. The application of this principle in non-life insurance is limited due to a high heterogeneity of accepted risks;

- The principle of variance is based on the assumption that $p(t)=E(Z(t))+\alpha \operatorname{Var}(Z(t))$, for some $\alpha>0$, in which a safety margin is proportional to the variance of expected losses;

- The principle of standard deviation, also based on the net premium principle, is often used in non-life insurance. According to this principle, the expected value of a loss must be covered by a premium including safety loading, which is proportional to the standard deviation of the expected damage, i.e. $p(t)=E(Z(t))+\alpha \sqrt{\operatorname{Var}(Z(t))}$, for $\alpha>0$. Due to its linearity when it comes to proportional changes in claims, this principle is mostly used in property and casualty insurance. 


\section{CONCLUSION}

Insurance companies are institutions absorbing undesirable effects of their users' risks. Due to the influence of political and legal as well as social and climatic factors, rapid changes in the business and economic environment require a comprehensive and dynamic risk treatment, especially in non-life insurance. Therefore, $\mathrm{H}$. Cramer said that "the goal of risk theory is to provide a mathematical analysis of the fluctuations in the insurance business and to suggest various means of protection against their adverse effects" (Cramer, 1930, 7). The oldest approach to this problem is the individual-risk theory. It observes individual insurance policies, with different characteristics and risk profiles, so that the overall risk of doing business is obtained via the summing of all the claims arising from the entire portfolio of insurance policies. However, the claims arise randomly, so the risk process is a stochastic process. Thus, the collective risk model, based on the application of stochastic processes in insurance, has a very important role in the development of academic actuarial science. In this model, claims are treated aggregately, at the level of the portfolio as a whole. Although the risk process is considered as one of the simpler forms of stochastic processes, there is still much to do to have it applied.

The mathematical foundation has applied some necessary, however unrealistic, assumptions in the model construction and development for both the claim number process and the total amount of claims paid process. Despite their broad significance, the main disadvantages and limitations of theoretical considerations pertain to the determination of the distribution function which realistically reflects the statistics of insurers. The executed simulations of the proposed model use some of the known distribution functions, which can almost never represent insurers' portfolio adequately. Today, a large number of papers focus on the determination of the general distribution functions, which will increase the correspondence of the obtained results with a reality (Cossette et al, 2002; Embrechts et al, 1997; Kaas et al, 2001). Moreover, a lot of work is focused on the construction of a model which will include inflation in determining the total amount of the compensation paid. In order to have it practically applied, which is the direction in which this theory is to further develop, it is necessary that the fact that claims are not paid at the same time or immediately after the arrival of a request to an insurance company should be taken into account. Also, special attention should be paid to the costs accompanying the treatment and settlement of claims.

The main results of the collective risk theory, which are presented in the paper, are indicative of a wide range of the modifications, modeling and simulations of events that may occur. The main disadvantage of theoretical considerations, including this paper, is their currently limited applicability in the practical business environment. However, as the range of the risk of non-life insurers in an increasingly turbulent business environment is in a constant increase, real consequences can no longer be predicted by using only business statistics. It is indisputable that the collective risk model represents a broad scientific field, engaging numerous scientists producing growingly concrete results when the convergence of theory and concrete business problems are concerned. Hence, the combination of visualization and stochastic actuarial experience is a strong mechanism to solve an increasingly complex insurers' risk.

\section{REFERENCES}

Albers, W. (1999). Stop-loss premiums under dependence. Insurance: Mathematics and Economics 24, 173-185.

Andersen, E. S. (1957). On the collective theory of risk in case of contagion between claims. Bulletin of the Mathematics and its Application, 12, 275-279.

Asmussen, S. (2000). Ruin Probabilities. Singapore: World Scientific.

Bowers, N. L., Gerber, H. U., Hickman, J. C., Jones, D. A., \& Nesbitt, C. J. (1997). Actuarial Mathematics. Schaumburg, Illinois: Society of Actuaries.

Cossette, H., Gaillardetz, P., Marceau, E., \& Rihoux, J. (2002). On two dependent individual risk models. Insurance: Mathematics and Economics, 30, 153-166.

Cramer, H. (1930). On the mathematical theory of risk. Stockholm, Skandia Jubilee Volume. 
Cramer, H. (1955). Collective risk theory: a survey of the theory from the point of view of the theory of stochastic process. 7th Jubilee Volume of Skandia Insurance Company. Stockholm, 5-92,

Daykin, C. D, Pentikäinen, T., \& Pesonen, M. (1994). Practical Risk Theory for Actuaries. London, UK: Chapman \& Hall.

Dickson, D. C. M. (1991). The probability of ultimate ruin with a variable premium loading - a special case. Scandinavian Actuarial Journal, 75-86.

Embrechts, P., \& Klüppelberg, C. (1993). Some Aspects of Insurance Mathematics Theory of Probability and its Application. Theory ov Probability and Its Application, 38, 262295.

Embrechts, P., Kluppelberg, C., \& Mikosch, T. (1997). Modelling Extremal Events for Insurance and Finance. New York, NY: Springer.

Genest, C., Marceau, E., \& Mesfioui, M. (2003). Compound Poisson approximation for individual models with dependent risks. Insurance: Mathematics and Economics, 32, 73-85.

Grandell, J. (1997). Mixed Poisson Processes. London, UK: Chapman \& Hall.

Kaas, R., Goovaerts, M., Dhaene, J., \& Denuit, M. (2001). Modern Actuarial Risk Theory. Boston, USA: Kluwer Academic Publishers.

Kingman, J. F. C. (1993). Poisson Processes. Oxford: Clarendon Press.

Kling, B. M., \& Goovaerts, M. (1993). A note on compound generalized distributions. Scandinavian Actuarial Journal, 1, $60-72$.
Klugman, S., Panjer, H. H., \& Willmot, G. E. (1998). Loss Models: from Data to Decisions. New York, NY: John Wiley.

Landsman, Z., \& Sherris, M. (2001). Risk measures and insurance premium principles. Insurance: Mathematics and Economics, 29(1), 103-115.

Lundberg, F. (1932). Some supplementary research on the collective risk theory. Skandinavisk Aktuarietidskrift, 15, 137158.

Mikosch, T. (2004). Non-Life Insurance Mathematics: An Introduction with Stochastic Processes. Berlin, Germany: Springer.

Minkowa, L. (2010). Insurance Risk Theory. Lecture Notes. from www.fmi.uni-sofia.bg

Panjer, H. H., \& Willmot, G. E. (1992). Insurance Risk Models. Schaumburg, Illinois: Society of Actuaries.

Ramasubramanian, S. (2005). Poisson process and insurance: an introduction. Prepared for a series of lectures given at a Refresher course in Applied Stochastic Processes, held at the Indian Statistical Institute, New Delhi, from http://www. math.iisc.ernet.in

Rolski, T., Schmidli, H., Schmidt, V., \& Teugels, J. (1999). Stochastic Processes for Insurance and Finance. New York, NY: Wiley and Sons.

Shari, A. H., \& Panjer, H. H. (1995). An improved recursion for the compound generalize Poisson distribution. Mitteilungen der Vereinigung Schweizerischer Versicherungsmathematiker, 1, 93-98.

Zlata Đurić works as a teaching assistant in the disciplines of Mathematics in Economics and Financial and Actuarial Mathematics at the Faculty of Economics of the University of Kragujevac. Her key research interest is the application of the mathematical apparatus to economic problems, particularly financial mathematics and insurance models. 


\title{
KOLEKTIVNI MODEL RIZIKA U NEŽIVOTNOM OSIGURANJU
}

\author{
Zlata Đurić* \\ Ekonomski fakultet Univerziteta u Kragujevcu
}

Poslovanje osiguravajućih društava, bazirano na preuzimanju različitih profila rizika, praćeno je fluktacijom poslovnog okruženja. Kompleksnost predviđanja finansijskog efekta zahteva za odštetama u neživotnom osiguranju leži u samoj strukturi obaveza osiguravača, čija visina ne može biti određena u trenutku naplate premije. Analizom ključnih procesa osiguranja, teorija rizika fokusira se na modeliranje potraživanja, kao finansijskih posledica nepredvidivih događaja. Pored toga, ona daje i odgovor na pitanje koliku premiju treba naplatiti da bi se izbegao bankrot, pa samim tim, predstavlja kompleksnu i aktuelnu istraživačku oblast. U radu su predstavljeni osnovni rezultati kolektivnog modela rizika za ključne procese poslovanja neživotnih osiguravajućih društava: proces prebrajanja zahteva za odštetama i proces ukupne sume isplaćenih odšteta. Ovi procesi se, u teoriji rizika, tretiraju kao stohastički procesi, što pruža širok dijapazon mogućnosti za modeliranje i simulaciju konkretnih poslovnih problema.

Ključne reči: neživotno osiguranje, teorija rizika, stohastički proces, Poisson-ov proces, principi obračuna premije

\section{JEL Classification: C13, C43, C46}

\section{UVOD}

Suočavanje sa rizicima je generisalo formiranje i funkcionisanje osiguravajućih društava koja, svojim korisnicima, pružaju mogućnost disperzije i minimiziranja gubitaka. Osiguranici prenose svoje rizike na osiguravača, koji, formirajući dovoljno velike grupe srodnih rizika, gubitak svakog osiguranika smanjuje, uplatom odgovarajuće premije. Osnovni uzrok svih dilema neživotnih osiguravača leži u

\footnotetext{
* Korespondencija: Z. Đurić, Ekonomski fakultet Univerziteta u Kragujevcu, Đ. Pucara 3, 34000 Kragujevac, Srbija; e-mail: zdjuric@kg.ac.rs
}

činjenici da se premije uplaćuju pre nastupanja bilo kakvog nepovoljnog događaja, pa je neophodno proceniti kolika je verovatnoća realizacije, kao i monetarni iznos gubitka, koji mora biti kompenzovan. Teorija verovatnoće i statistike osiguravačima pruža osnov da nesrećne događaje posmatraju kao pojave koje se, zbog određenih pravilnosti, mogu predviđati i modelirati (Embrechts \& Klüppelberg, 1993). Primena teorije rizika u neživotnom osiguranju predstavlja još moćniji instrument za analiziranje i definisanje sve kompeksnijih rizika poslovanja. Preuzimanje različitih rizika, inicira sledeća tri osnovna pitanja, na koja, prvenstveno, aktuari neživotnog osiguranja moraju fokusirati svoju pažnju, da bi adekvatno izvršili zaštitu korisnika: 
- Koliko preuzetih rizika se može realizovati u određenom vremenskom intervalu, odnosno, koliko zahteva za nadoknadama mogu očekivati na osnovu naplaćenih polisa?

- Koliki novčani iznos treba obezbediti za isplatu pristiglih potraživanja, odnosno, kolika je prosečna očekivana visina potraživanja?

- Koliku premiju treba naplatiti od osiguranika, koja bi apsorbovala nastala potraživanja, ali i obezbedila prihod osiguravačima?

Primena teorije rizika $\mathrm{u}$ neživotnom osiguranju, praćena je primedbama na ograničeni, praktični značaj u poslovnom svetu, tako da je dugo bila ignorisana a teorijski i matematički razvijana uglavnom kod skandinavskih naučnika. Međutim, danas ona predstavlja veliki istraživački izazov za brojne matematičare, ali i aktuare, zbog širokog okvira i logičnog konteksta unutar kojeg se prirodne fluktacije, koje nastupaju u realnim poslovnim procesima, mogu simulirati.

Solventnost II, kao nov, ažurirani skup regulatornih uslova za osiguravajuća društva, koja posluju u Evropskoj uniji, zahteva kompletan tretman rizika i merenje solventnosti zasnovano na riziku, što je aktuelizovalo primenu teorije rizika. Pored tradicionalnih metoda, sve je prisutnija potreba za novim, dinamičkim pristupom, koji je baziran na stohastičkom konceptu ostvari.vanja štetnih događaja.

Osiguravači su, generalno, zainteresovani za ukupne isplate koje mogu uslediti iz portfolia osiguranja. Ukoliko se sadašnja vrednost ukupnih mogućih isplata posmatra kao zbir pojedinačnih isplata, radi se o individualnom modelu rizika. Drugi model, koji posmatra agregatne iznose potraživanja, koja nastaju iz svih naplaćenih polisa, poznat je kao kolektivni model rizika, koji je novijeg porekla, ali je zbog svoje aplikativnosti u značajnoj meri nadmašio stariji, individualni model.

Predmet ovog rada je modeliranje ključnih procesa $\mathrm{u}$ poslovanju osiguravajućih društava: procesa prebrajanja zahteva za isplatu šteta i procesa ukupne sume isplaćenih odšteta. Cilj rada je da prezentira prednosti $\mathrm{i}$ mane kolektivne teorije rizika $u$ analiziranju ovih problema, ukazujući na mogućnosti njihove primene i pravce daljeg razvoja. Samim tim, ključna hipoteza od koje se $u$ radu polazi je: teorija rizika, iako nije mnogo aplikativna u praktičnom radu, pruža širok okvir za praćenje, analiziranje i predviđanje brojnih rizičnih situacija i daje smernice za ublažavanje i prevazilaženje problema koji mogu nastupiti.

Polazeći od definisanog predmeta i cilja, u radu će biti prvo predstavljen opšti model teorije rizika u neživotnom osiguranju, zatim, biće analizirana primena Poisson-ovog procesa i njegovih modifikacija $\mathrm{u}$ procesu prebrajanja zahteva. Integracijom ovog i procesa ukupne sume isplaćenih šteta, polje istraživanja postaje vrlo kompleksno, ali dominantno pri postavljanju osnovnih principa kvantifikovanja premije.

\section{KOLEKTIVNI MODEL RIZIKA}

Matematički modeli u teoriji neživotnog osiguranja, analiziraju potraživanja za odštetama, na osnovu kojih daju odgovor na pitanje koliku premiju treba naplatiti da bi se izbegao bankrot. Potraživanja pristigla $u$ osiguravajuće društvo mogu biti tretirana kao slučajne promenljive, koje preslikavaju skup ishoda realizacije nepovoljnih osiguranih događaja (potraživanja) na skup realnih brojeva (monetarni iznos isplata), odnosno, kao preslikavanja $X: \Omega \rightarrow R$, gde je $\Omega$ skup elementarnih događaja, a R skup realnih brojeva. Način i verovatnoća nastupanja potraživanja, odnosno, monetarnih isplata, predstavljaju raspored verovatnoća ovih slučajnih promenljivih. Svakoj slučajno promenljivoj možemo pridružiti funkciju rasporeda, $F_{X}$, koja ne opisuje stvarni ishod slučajne promenljive $X$, već nam ukazuje na to kako su raspoređene moguć vrednosti za $X$. Funkcija $F_{X}(x): R \rightarrow[0,1]$, definisana sa

$F_{X}(x)=P(\omega \in \Omega \mid X(\omega) \leq x)=P(X \leq x)$, za $x \in R$, je funkcija rasporeda slučajne promenljive $X$ i predstavlja verovatnoću da slučajna promenljiva $X$ uzme vrednosti manje od ili jednaku $x$. U kontekstu osiguranja, ukoliko slučajna promenljiva predstavlja iznos potraživanja nekog osiguranika, funkcija rasporeda je verovatnoća da ukupan iznos štete posmatranog osiguranika bude manji ili jednak nekom fiksiranom iznosu $x$. Za neprekidnu slučajnu promenljivu, funkcija rasporeda 
je $F_{X}(x)=P(X \leq x)=\int_{-\infty}^{x} g(x) d x, \quad x \in R$, gde je $g(x)$ funkcijagustinerasporedaverovatnoća.Najvažnije numeričke karakteristike slučajne promenljive dobijamo pomoću očekivane vrednosti i varijanse. Očekivana vrednost, ili očekivanje diskretne slučajne promenljive, je: $E(X)=\sum_{i=1}^{n} x_{i} \cdot p_{i}$, dokje za neprekidnu slučajnu promenljivu $E(X)=\int_{-\infty}^{+\infty} x g(x) d x$. Varijansa je, često, korišćena kao jedan od indikatora homogenosti populacije ili uzorka. Za diskretnu slučajnu promenljivu, varijansa je:

$\operatorname{Var}(X)=\sigma^{2}=E(X-E(X))^{2}$, tako da ona predstavlja meru odstupanja slučajne promenljive od njene očekivane vrednosti. Za neprekidnu slučajnu promenljivu varijansa je: $\sigma^{2}=\int^{+\infty}(x-E(X))^{2} \cdot g(x) d x$. Pojam slučajne promenljive je nezavisan od vremena. Međutim, dosta procesa u poslovanju treba analizirati i pratiti njihove slučajne realizacije $\mathrm{u}$ vremenu, tako da je neophodno uključiti i vremensku komponentu. Slučajna promenljiva $X$, čije se realizacije prate u vremenu označava se sa: $X_{t}$ ili $X(t)$. Ako je $T \subset R$ skup vremena, tada za svako $t \in T$ je određena familija slučajnih promenljivih $X_{t}$, koja definiše stohastički proces. Stohastički proces $X=\left\{X_{t}, t \in R\right\}$ može se tretirati i kao funkcija dve promenljive i definisati sa $X: T^{x} \Omega \rightarrow K$, gde je $K$ skup stanja, odnosno, skup koji sadrži sve vrednosti posmatranog procesa. Za izabrano vreme $t \in T$ i elementarni događaj $\omega \in \Omega$, realizacija procesa se označava sa $X(t, \omega)$. Samim tim, ako fiksiramo vreme, tada je funkcija $\omega \rightarrow X(t, \omega)$ slučajna promenljiva koja opisuje realizacije procesa $\mathrm{u}$ budućem trenutku $t$, a u slučaju da fiksiramo događaj $\omega \in \Omega$, tada funkcija $t \rightarrow X(t, \omega)$ opisuje realizaciju procesa $X$ tokom vremena. Ova funkcija vremena je realizacija ili trajektorija stohastičkog procesa. Pri tome, ako je skup $T$ prebrojiv, radi se o diskretnom slučajnom procesu ili o nizu slučajnih promenljivih dok, u suprotnom, imamo neprekidan proces. 3

$\mathrm{Za}$ modeliranje procesa neophodno je uvesti pretpostavke koje su realne i verno opisuju osnovne karakteristike problema, ali takve da se mogu matematički formulisati i da se njihova svojstva i implikacije lako mogu dokazati. "U kolektivnom modelu rizika se polazi od sledećih hipoteza (Ramasubramanian, 2005, 2):

1. Ukupan broj zahteva, $B$, pristiglih $\mathrm{u}$ datom vremenu, je slučajna promenljiva. Zahtevi pristižu u osiguravajuće društvo u vremenima $\{T i\}$, za koja važi $0 \leq T_{1} \leq T_{2} \leq \ldots$, i ona predstavljaju vremena dospeća zahteva;

2. Svaki zahtev, pristigao u vremenu $T i$ indukuje isplatu štete $X_{i}$, odnosno, iznos potraživanja. Niz $\left\{X_{i}\right\}$ je niz nenegativnih, nezavisnih slučajnih promenljivih sa istom funkcijom rasporeda;

3. Proces veličine zahteva $\left\{X_{i}\right\}$ i proces vremena dospeća $\{T i\}$ su međusobno nezavisni. Takođe, proces veličine i broja zahteva, $\left\{X_{i}\right\}$ i $B$ su nezavisni."

Dva najvažnija procesa koji prate poslovanje osiguravača su proces broja zahteva i proces ukupne sume isplaćenih šteta. Kako se oba procesa prate $u$ vremenu, oni predstavljaju stohastičke procese. Pri tome, proces broja zahteva, odnosno, proces broja nastalih šteta definiše se sa:

$B(t)=\max \left\{i \geq 0: T_{i} \leq t\right\}$

i predstavlja broj zahteva pristiglih $\mathrm{u}$ vremenu $t \geq 0$, dok proces ukupne sume isplaćenih šteta je

$Z(t)=X_{1}+\ldots .+X_{B(t)}=\sum_{i=1}^{B(t)} X_{i}, t \geq 0$.

Kako je deterministički indeks $n$, parcijalne sume $Z_{n}=X_{1}+X_{2}+\ldots+X_{n}$, zamenjen slučajnom promenljivom $B(t)$, proces $Z=(Z(t), t \geq 0)$ je slučajan proces parcijalne sume, koji se cesto naziva i složen ili zbirni proces.

\section{MODELIRANJE PROCESA BROJA ZAHTEVA}

Centralno $\mathrm{i}$ dominantno mesto $\mathrm{u}$ matematici neživotnog osiguranja, a posebno $u$ teoriji 
kolektivnog rizika, zauzima Poisson-ov proces, koji je uveo F. Lundberg (1932) kao model za proces prebrajanja zahteva $\{B(t): t \geq 0\}$, gde je $B(t)$ slučajna promenljiva.

Prema klasičnoj definiciji teorije verovatnoće, za neku celobrojnu slučajnu promenljivu $Y$ se kaže da ima Poisson-ov raspored ako je: $P(Y=k)=e^{-\lambda} \frac{\lambda^{k}}{k !}, \quad$ za $k \in\{0,1,2 \ldots\}$ i $\lambda>0$. Poisson-ova slučajna promenljiva se koristi kao model za broj telefonskih poziva u jedinici vremena, broj automobila ili autobusa koji su prošli kroz neku tačku u jedinici vremena, broj korisnika koji su pristupili nekoj internet stranici, broj radioaktivnih čestica $u$ jedinici vremena, itd. Ona ima veoma retku, ali vrlo korisnu osobinu da je $E(Y)=\operatorname{var}(Y)=\lambda$.

Poisson-ov proces prati realizaciju pojavljivanja određenog događaja tokom vremena $\mathrm{i}$ trenutke $\mathrm{u}$ kojima se događaj desio, tako da je našao široku primenu za modeliranje retkih događaja, odnosno događaja za koje u kratkom vremenskom intervalu je moguća najviše jedna realizacija. "Poisson-ov proces je slučajan proces, definisan na vremenskom skupu, kao familija slučajnih promenljivih $\{B(t)\}, t \in T$, gde je skup $T=[0,+\infty)$, ako je ispunjeno (Ramasubramanian, 2005, 3):

(1) $B(t)$ je nenegativna celobrojna slučajna promenljiva za koju važi $B(0) \equiv 0, \forall t \geq 0$, što znači da ne postoji potraživanje u vremenu $t=0$;

(2) $\{B(t): t \geq 0\}$ je neopadajući proces, odnosno ako je $0 \leq s<t$ tada je $B(t) \leq B(s)$, gde $B(t)-B(s)$ označava broj zahteva pristiglih u vremenskom intervalu $(\mathrm{s}, \mathrm{t}]$;

(3) $\{B(t): t \geq 0\}$ ima nezavisne priraštaje, tako da za $0<t_{1}<t_{2}<\ldots<t_{n}<\infty$ broj zahteva pristiglih $\mathrm{u}$ disjunktnim vremenskim intervalima $B\left(t_{1}\right)$, $B\left(t_{2}\right)-B\left(t_{1}\right), \ldots \ldots \ldots, B\left(t_{n}\right)-B\left(t_{n-1}\right)$, za $n=1,2, \ldots$ su nezavisne slučajne promenljive;

(4) verovatnoća pristizanja određenog broja zahteva $\mathrm{u}$ nekom vremenskom intervalu zavisi samo od dužine tog intervala, tako da proces prebrajanja ima stacionarne priraštaje, tj. za $0 \leq s<t$ i $h>0$, nezavisne slučajne promenljive $B(t)-B(s)$ i $B(t+h)-B(s+h)$ imaju isti raspored;

(5) verovatnoća pristizanja dva ili više zahteva u određenom vremenskom intervalu je zanemarljivo mala, odnosno, $P(B(h) \geq 2)=o(h)$, tj. $P(B(t+h)$ $-B(t) \geq 2)=o(h)$, gde $o(h)$ predstavlja beskonačno malu veličinu sa osobinom $\lim _{h \rightarrow 0} \frac{o(h)}{h}=0$;

(6) u veoma kratkom vremenskom intervalu, verovatnoća pristizanja jednog zahteva je približno proporcionalna dužini intervala, tako da postoji $\lambda>0$ takvo da $P(B(h)=1)=\lambda h+o(h)$, kada $h \rightarrow 0$. Broj $\lambda$ predstavlja stopu pristizanja zahteva."

Iako Poisson-ov proces nije najrealniji proces za prebrajanje zahteva, zbog brojnih atraktivnih i aplikativnih osobina, razvijanih i dokazivanih više decenija, on predstavlja referentnu tačku $u$ modeliranju. Limitiranost standardnog Poisson-ovog procesa se može ublažiti, i sami modeli proširiti, raznim modifikacijama standardnog Poisson-ovog procesa, koje je detaljno analizirao J. F. C. Kingman (1993). Time se za modeliranje procesa prebrajanja zahteva pojavljuju još dva, dosta šira i realnija procesa: proces obnavljanja i mešoviti Poisson-ov proces.

"Za formulisanje i matematičko modeliranje procesa prebrajanja potraživanja, polazi se od prirodnih, ali i neophodnih, sledećih pretpostavki (Minkowa, 2010, 31):

- $B(t) \geq 0$

- $B(t)$ je ceo broj

- ako je $0 \leq s<t$, tada je $B(t) \leq B(s)$,

- $B(t)-B(s)$, za $s<t$, predstavlja broj zahteva pristiglih u intervalu $(s, t] . "$

Definicija Poisson-ovog procesa implicira da, za svaki stohastički proces, a samim tim i proces prebrajanja zahteva $\{B(t): t \geq 0\}$ i za $s \geq 0, k=0,1,2, \ldots$ važi:

$P(B(t+s)-B(s)=k)=$

$\mp P(B(t)=k)=\frac{(\lambda t)^{k}}{k !} e^{-\lambda t}$

odnosno, proces prebrajanja zahteva je homogen Poisson-ov proces sa stopom pristizanja zahteva $\lambda$, gde je $\lambda$ konstanta. Dokaz i različiti pristupi izvođenju ovog 
rezultata mogu se naći u radovima brojnih autora, kao što su N. L. Bowers i ostali (1997), C. T. Daykin i ostali (1994), S. Klugman i ostali (1998).

Za proces prebrajanja zahteva, sa aspekta osiguranja, bitno je i vreme između pristizanja dva uzastopna zahteva. Ako vreme pristizanja n-tog zahteva, odnosno vreme čekanja do prispeća n-tog zahteva definišemo sa:

$T_{n}=\inf \{t \geq 0: B(t)=n\}, n=1,2, . ., T_{0}=0$,

njemu možemo pridružiti niz vremena između dospeća dva uzastopna zahteva $A_{i}$, definisano sa $A_{i}=T_{i}-T_{i-1}$. Analogno ovim definicijama imamo da

$\forall s:\left\{T_{1}>s\right\}=\{B(s)=0\}$

odakle je

$P\left(A_{1}>s\right)=P(B(s)=0)=e^{-\lambda s}$

Induktivno se dobija da za Poisson-ov proces $\{B(t): t \geq 0\}$ sa stopom rasta $\lambda$, slučajne promenljive $A_{i}$ su nezavisne slučajne promenljive koje imaju eksponencijalni raspored sa parametrom $\lambda \operatorname{tj} A_{i}: \varepsilon(\lambda)$,

tako da je $E\left(A_{i}\right)=\frac{1}{\lambda}, \forall i, \lambda>0$.

Kako $T_{n}=A_{1}+A_{2}+\ldots+A_{n}$ predstavlja zbir slučajnih promenljivih sa eksponencijalnim rasporedom, znači da vreme pristizanja n-tog zahteva $T_{n}$ ima gama raspored, $T_{n}: \Gamma(n, \lambda)$ (Rolski, et al, 1999).

Jedna od ključnih karakteristika Poisson-ovog procesa $\{B(t): t \geq 0\}$ je činjenica da je vreme između prispeća dva uzastopna zahteva slučajna promenljiva sa eksponencijalnim rasporedom sa stopom $\lambda$. Druga bitna karakteristika procesa $\{B(t): t \geq 0\}$ je da su ova vremena nezavisna. Ove dve karakteristike nam daju još jedan način uopštavanja Poisson-ovog procesa. Naime, možemo pretpostaviti da nenegativne, nezavisne slučajne promenlije $A_{i}$, sa istim rasporedom mogu imati ma koji, bilo diskretan ili apsolutno neprekidan raspored. Ova pretpostavka nas dovodi do procesa obnavljanja (Asmussen, 2000), koji daje veću fleksibilnost u izboru rasporeda za vremena $A_{i}$. Za razliku od Poisson-ovog procesa, gde $B(t)$ ima Poissonov raspored za svako $t$, kod procesa obnavljanja ovo svojstvo ne važi, tako da raspored za $B(t)$ u principu nije poznat, pa se određivanje verovatnoće događaja $B(t)=n$ svodi na određivanje očekivanja slučajne promenljive $B(t)$ (Panjer \& Willmot, 1992).

Takođe, kako za vreme pristizanja n-tog zahteva, $T_{n}=\sum_{i=1}^{n} A_{i}$, važi relacija:

$$
T_{n} \leq s \Leftrightarrow B(t)=n
$$

U opštem slučaju teško je odrediti i raspored za $T_{n}$, ali se zna da: ako $A_{i}: \varepsilon(\lambda)$ tada $T_{n}: \Gamma(n, \lambda)$ a ako $A_{i}: \operatorname{Poi}(\lambda)$ tada $T_{n}$ : Poi $(n, \lambda)$. Istraživanja brojnih naučnika na polju procesa obnavljanja (Kling \& Goovaerts, 1993) dovela su do moćne matematičke teorije - teorije obnavljanja, koja omogućava da se sasvim precizno odredi očekivani broj zahteva $E(B(t))$ za veliko t. Prema strogom zakonu velikih brojeva, ako je očekivanje vremena prispeća dva uzastopna zahteva $\mathrm{E}\left(A_{i}\right)=\lambda^{-1}$ konačno, tada

$\lim _{t \rightarrow \infty} \frac{B(t)}{t}=\lambda$

Takođe, prema osnovnoj teoremi obnavljanja važi:

$\lim _{t \rightarrow \infty} \frac{E(B(t))}{t}=\lambda$

Najprecizniju informaciju o očekivanju vremena pristizanja zahteva daje Blackwell-ova teorema obnavljanja, po kojoj

$E(B(t, t+h]) \rightarrow \lambda h, t \rightarrow \infty$

Znači, očekivani broj obnavljanja na intervalu $(t, t+h$ ] za dovoljno veliko $t$ je proporcionalan dužini intervala i nezavisan od $t$.

Osnovna pretpostavka, da je prosečna stopa pojavljivanja zahteva konstanta, nije realna jer pristizanja zahteva često zavisi od vremenskih uslova. Posmatrajući parametar $\lambda$ kao funkciju vremena $t$, model homogenog Poisson-ovog procesa može se proširiti na nehomogen Poisson-ov proces. On, takođe, startuje sa nulom, ima nezavisne priraštaje, za koje važi da za $0 \leq s<t$, priraštaj $B(t)-B(s)$ ima Poisson-ov raspored sa parametrom $\int_{s}^{t} \lambda(y) d y$. Pritome, funkcija $\mu(t)=\int_{0}^{t} \lambda(y) d y, \quad$ predstavlja funkciju srednje 
vrednosti nehomogenog Poisson-ovog procesa, za neke nenegativne merljive funkcije $\lambda$. Ukoliko je funkcija srednje vrednosti linearna, tj. $\mu(t)=\lambda t$, radi se o homogenom Poisson-ovom procesu, a $u$ suprotnom o nehomogenom. Uvođenjem funkcije intenziteta $\lambda(t)$ proces pristizanja zahteva može se pratiti i modelirati i prema sezonskim trendovima. Ukoliko zahtevi pristižu iz heterogene grupe osiguranika, stopa pristizanja zahteva varira od jedne do druge polise, tako da se $\lambda(t)$ može posmatrati kao slučajna promenljiva $\Lambda(t), \forall t>0$. Skup $\{\Lambda(t), t \geq 0\}$ je stohastički proces, pa, samim tim, proces $\{B(t): t \geq 0\}$ predstavlja dvostruki stohastički Poisson-ov proces. Tretirajući $\lambda$ kao slučajnu promenljivu koja ne zavisi od vremena, stohastički proces $\{B(t): t \geq 0\}$ predstavlja mešovit Poisson-ov proces, koji je još moćnija generalizacija opšteg Poisson-ovog procesa. Mešoviti Poisson-ov proces gubi neke osobine Poisson-ovog procesa (priraštaji su međusobno zavisni, raspored za $B(t)$ u opštem slučaju nije Poisson-ov), ali se dobija mnogo veći izbor trajektorija nego kod Poisson-ovog procesa i procesa obnavljanja (Grandell, 1997).

\section{MODELIRANJE PROCESA UKUPNE SUME ISPLAĆENIH ODŠTETA}

Analiziranje procesa potraživanja se proširuje, ukoliko se u razmatranje, osim broja pristiglih zahteva, uključi i veličina potraživanja, koju ti zahtevi indukuju. Zbir pojedinačnih potraživanja, odnosno, agregatni iznos potraživanja, predstavlja ključni problem kako u praksi tako i u teorijskim razmatranjima. Naime, kako su i broj zahteva i iznos potraživanja stohastičke promenljive, ovde imamo dvostruki stohastički model agregatnog iznosa potraživanja. $U$ zavisnosti od izbora procesa prebrajanja $B$, dobijamo različite modele za proces ukupnog iznos isplaćenih odšteta do vremenskog trenutka $t$ :

$$
Z(t)=X_{1}+\ldots .+X_{N(t)}=\sum_{i=1}^{B(t)} X_{i}, t \geq 0
$$

"Jedan od najpopularnijih i najkorisnijih modela $u$ matematici neživotnog osiguranja predstavlja CramerLundberg-ov model (Cramer, 1955), koji kombinuje iznos zahteva i vreme pristizanja zahteva, uz sledeće pretpostavke (Mikosch, 2009, 18):

- proces prebrajanja zahteva $B(t)=\max \left\{i \geq 0: T_{i} \leq t\right\}$ je homogen Poisson-ov proces sa stopom $\lambda>0, \mathrm{u}$ kojem se zahtevi realizuju u trenucima pristizanja $0 \leq T_{1} \leq T_{2} \leq \ldots$;

- zahtev pristigao u trenutku $T_{i}$ indukuje isplatu štete $X_{i}$. Niz $\left\{T_{i}\right\}$ je niz nenegativnih, nezavisnih slučajnih promenljivih sa istom funkcijom rasporeda;

- nizovi $\left\{X_{i}\right\}$ i $\left\{T_{i}\right\}$ su međusobno nezavisni".

Ako posmatramo diskontovanu sumu, tj. sadašnju vrednost kumulativnog iznosa zahteva u vremenskom intervalu $[0, \mathrm{t}]$ :

$Z_{0}(t)=\sum_{i=1}^{B(t)} e^{-V_{i}} X_{i}, t \geq 0$

gde je $r>0$ kamatna stopa, u Cramer-Lundberg-ovom modelu je:

$E\left(\sum_{i=1}^{B(t)} e^{-r T_{i}} X_{i}\right)=\lambda \frac{1}{r}\left(1-e^{-r t}\right) E\left(X_{1}\right)$

očekivani iznos potreban za izmirenje zahteva pristiglih u posmatranom vremenskom intervalu.

Osiguravače, generalno, interesuje red veličine za $Z(t)$, pa samim tim i funkcije rasporeda za $Z(t)$. Kako je određivanje rasporeda za $Z(t)$ veoma komplikovan problem, rešenje predstavlja simulacija modela $\mathrm{i}$ dobijanje grube procene za očekivanje i varijansu za $Z(t)$.

Očekivanje ukupnog iznosa isplaćenih šteta nam ukazuje na njegovu prosečnu veličinu. $\mathrm{Uz}$ pretpostavku nezavisnosti između $X_{i}$ i $B$, jednostavno se može dobiti, ako su $E(B(t))$ i $E\left(X_{1}\right)$ konačni:

$E(Z(t))=E\left[E\left(\sum_{i=1}^{B(t)} X_{i} \mid B(t)\right)\right]=$
$=E\left(B(t) E X_{1}\right)=E(B(t)) E\left(X_{1}\right)$

Kako je u Cramer-Lundberg-ovom modelu proces $B(t)$ homogen Poisson-ov proces, tada je $\mathrm{E}(\mathrm{B}(\mathrm{t}))=\lambda \mathrm{t}$, gde je $\lambda$ stopa intenziteta homogenog Poisson-ovog procesa, tako da iz (14) dobijamo: 


$$
E(Z(t))=\lambda t E\left(X_{1}\right)
$$

Da bi imali kompletniju informaciju o rasporedu za $Z(t)$, treba kombinovati informaciju o očekivanju sa varijansom $\operatorname{Var}(Z(t))$, za koju važi:

$$
\begin{aligned}
\operatorname{Var}(Z(t)) & =E(B(t)) \operatorname{Var}\left(X_{1}\right)+ \\
& +\operatorname{Var}(B(t))\left(E\left(X_{1}\right)\right)^{2}
\end{aligned}
$$

Kako u Cramer-Lundberg-ovom modelu važi da je $E(B(t))=\operatorname{Var}(B(t))=\lambda t$, dobijamo:

$$
\operatorname{Var}(Z(t))=\lambda t E\left(X_{1}^{2}\right)
$$

Još jedan istaknut model za proces $\{Z(t): t \geq 0\}$ je uveo Sparre-Andersen, (Andersen, 1957), a njegove implikacije proučavalo je više autora (Sharif \& Panjer, 1995; Genest et al, 2003), kod kojeg je proces $\{B(t): t \geq 0\}$ proces obnavljanja. Ali $u$ modelu obnavljanja, izvođenje procene očekivanja i varijanse nije jednostavno i ne daje ovako konkretne rezultate. Videli smo da, prema strogom zakonu velikih brojeva, ako je očekivanje vremena prispeća dva uzastopna $\underset{t \rightarrow \infty}{\text { zahteva }} E\left(A_{i}\right)=\lambda^{-1}<\infty$, tada $\frac{E(B(t))}{t} \rightarrow \lambda$ kada Time dobijamo da je :

$E(Z(t))=\lambda t E\left(X_{1}\right)(1+o(1)), t \rightarrow \infty$

i

$$
\begin{aligned}
\operatorname{Var}(Z(t)) & =\lambda t\left[\operatorname{Var}\left(X_{1}\right)+\operatorname{Var}\left(A_{1}\right) .\right. \\
& \left.\cdot \lambda^{2}\left(E\left(X_{1}\right)\right)^{2}\right](1+o(1))
\end{aligned}
$$

$\mathrm{Na}$ osnovu ovih rezultata dobijamo da očekivanje i varijansa asimptotski rastu skoro linearno kao funkcija vremena $t$. Ova informacija može biti vrlo korisna u praktičnom određivanju premije dovoljne za poravnjanje gubitaka, veličine $Z(t)$.

\section{PRINCIPI OBRAČUNA PREMIJE}

Novčani iznos koji osiguranik plaća osiguravaču kao nadoknadu za preuzimanje rizika je premija. Između rizika i premije postoji uska povezanost jer se visina premije određuje prema prosečnoj veličini rizika, čija se svaka promena mora odraziti na visinu premije. Posmatrajući premiju kao monetarnu isplatu osiguravača, u kontekstu opisanih procesa, očigledno je da će osiguravajuće društvo poslovati sa gubitkom ako premija bude manja od očekivanog iznosa isplata tj ako $p(t)<Z(t)$. Kako smo u prethodnim razmatranjima dobili da je $E(Z(t))=\lambda t E\left(X_{1}\right)(1+o(1))$, $t \rightarrow \infty$, logično je premiju odrediti tako da je

$p(t)=\lambda t E\left(X_{1}\right)(1+\rho)$

gde je $\rho$ pozitivna konstanta i predstavlja sigurnosni dodatak, odnosno doplatu za sigurnost.

$\mathrm{U}$ teoriji rizika postoje principi, koje sve premije $p(t)$ treba da zadovolje, poznati kao premijski principi. Da bi odredili premiju, kao preslikavanje neizvesnih budućih gubitaka u finansijski ekvivalent, aktuari su razvili brojne metode za determinisanje premijskog principa, (Albers, 1999; Dickson, 1991; Landsman et al, 2001), od kojih su bazični:

- Princip neto-premije je osnovni princip, po kojem je $p(t)=E(Z(t))$. On ne podrazumeva sigurnosni dodatak, jer aktuari često pretpostavljaju da rizik praktično ne postoji ako osiguravač proda dovoljno, identično distribuiranih i nezavisnih polisa;

- Princip očekivane vrednosti je zasnovan na prethodnom ali uključujući proporcionalni sigurnosni dodatak. Prema ovom principu $p(t)=(1+\rho) E(Z(t))$ za neko $\rho>0$. Ovaj princip se uglavnom koristi u životnom osiguranju. Primena ovog principa u neživotnim osiguranjima je ograničena zbog velike heterogenosti preuzetih rizika;

- Princip varijanse polazi od pretpostavke da je $p(t)=E(Z(t))+\alpha \operatorname{Var}(Z(t))$, za neko $\alpha>0$, po kojem je sigurnosni dodatak proporcionalan varijansi očekivanih gubitaka;

- Princip standardne devijacije je takođe zasnovan na principu neto-premije $\mathrm{i}$ često korišćen $u$ neživotnom osiguranju, prema kojem očekivana vrednost gubitka mora biti pokrivena premijom koja sadrži i sigurnosni dodatak proporcionalan standardnoj devijaciji očekivanih šteta, tj. $p(t)=E(Z(t))+\alpha \sqrt{\operatorname{Var}(Z(t))}$, za $\alpha>0$. Ovaj princip se, zbog linearnosti $u$ odnosu na 
proporcionalne promene odštetnih zahteva, najčešće koristi kod osiguranja imovine i nezgoda.

\section{ZAKLJUČAK}

Osiguravajuća društva su institucije koje apsorbuju nepoželjne efekte rizika svojih korisnika. Rapidne promene poslovnog i privrednog okruženja, zbog uticaja kako političkih, tako i pravnih, socioloških, klimatskih faktora, zahtevaju sveobuhvatni i dinamički tretman rizika, posebno $u$ neživotnom osiguranju. Zbog toga, H. Cramer navodi da je "cilj teorije rizika, da pruži matematičku analizu fluktacija u poslovima osiguranja i predloži različita sredstva zaštite od njihovih nepoženjnih efekata" (Cramer, 1930, 7). Najstariji pristup ovom problemu je individualna teorija rizika. Ona posmatra pojedinačne polise osiguranja, sa različitim karakteristikama i profilima rizika, tako da se ukupan rizik poslovanja dobija sumiranjem potraživanja nastalih iz svih polisa $\mathrm{u}$ portfoliu osiguranja. Međutim, kako potraživanja nastupaju slučajno, proces rizika je stohastički proces. Samim tim, kolektivni model rizika, zasnovan na aplikaciji stohastičkih procesa u osiguranju, ima veliku ulogu u razvoju akademske aktuarske nauke. $\mathrm{U}$ ovom modelu, potraživanja se tretiraju agregatno, odnosno, na nivou portfolia $\mathrm{u}$ celini. Iako se proces rizika smatra jednim od jednostavnijih oblika stohastičkih procesa, potrebno je još mnogo toga uraditi za njegovu praktičnu primenu.

Za konstrukciju i razvijanje modela kako za proces prebrajanja potraživanja, tako i za proces ukupne sume isplaćenih zahteva, matematička podloga je aplicirala neke neophodne, ali neraealne pretpostavke. Pored mnogostrukog značaja teorijskih razmatranja, njihov osnovni nedostatak i ograničenje je određivanje funkcije rasporeda, koja realno oslikava statistiku osiguravača. Izvršene simulacije predloženih modela, koriste neku od poznatih funkcija rasporeda, koja skoro nikada ne može adekvatno predstaviti portfolio osiguravača. Veliki broj radova je danas usmeren na izvođenje opštih funkcija rasporeda, koje će povećati korenspodenciju izvedenih rezultata sa realnošću (Cossette et al, 2002; Embrechts et al, 1997; Kaas et al, 2001). Osim toga, dosta radova je orijentisano na konstrukciju modela koji će uključiti inflaciju, pri određivanju ukupne sume isplaćenih odšteta. Za praktičnu primenu, kao pravac daljeg razvoja ove teorije, neophodno se mora uzeti u obzir činjenica da se potraživanja ne isplaćuju u isto vreme, niti odmah po pristizanju zahteva $u$ osiguravajuće društvo. Takođe, posebnu pažnju i tretman zahtevaju i troškovi koji prate obradu i rešavanje zahteva za isplatama.

Osnovni rezultati kolektivne teorije rizika, koji su predstavljeni $u$ radu, ukazuju na širok dijapazon modifikacija, modeliranja i simulacija događaja koji mogu nastupiti. Osnovni nedostatak teorijskih razmatranja, pa samim tim i ovog rada, je trenutna, limitirana aplikativnost u praktičnom poslovnom ambijentu. Međutim, kako se asortiman rizika neživotnih osiguravača, $u$ sve turbulentnijem poslovnom ambijentu, konstantno povećava, realne posledice se više ne mogu predvideti samo korišćenjem statističkih podataka poslovanja. Neosporno je da kolektivni model rizika predstavlja široko naučno polje, koje angažmanom brojnih naučnika daje sve konkretnije rezultate približavanja teorije konkretnim poslovnim problemima. Samim tim, spoj stohastičke vizuelizacije i aktuarskog iskustva predstavlja jak mehanizam u rešavanju sve kompleksnijih rizika osiguravača.

\section{REFERENCE}

Albers, W. (1999). Stop-loss premiums under dependence. Insurance: Mathematics and Economics 24, 173-185.

Andersen, E. S. (1957). On the collective theory of risk in case of contagion between claims. Bulletin of the Mathematics and its Application, 12, 275-279.

Asmussen, S. (2000). Ruin Probabilities. Singapore: World Scientific.

Bowers, N. L., Gerber, H. U., Hickman, J. C., Jones, D. A., \& Nesbitt, C. J. (1997). Actuarial Mathematics. Schaumburg, Illinois: Society of Actuaries.

Cossette, H., Gaillardetz, P., Marceau, E., \& Rihoux, J. (2002). On two dependent individual risk models. Insurance: Mathematics and Economics, 30, 153-166.

Cramer, H. (1930). On the mathematical theory of risk. Stockholm, Skandia Jubilee Volume. 
Cramer, H. (1955). Collective risk theory: a survey of the theory from the point of view of the theory of stochastic process. 7th Jubilee Volume of Skandia Insurance Company. Stockholm, 5-92,

Daykin, C. D, Pentikäinen, T., \& Pesonen, M. (1994). Practical Risk Theory for Actuaries. London, UK: Chapman \& Hall.

Dickson, D. C. M. (1991). The probability of ultimate ruin with a variable premium loading - a special case. Scandinavian Actuarial Journal, 75-86.

Embrechts, P., \& Klüppelberg, C. (1993). Some Aspects of Insurance Mathematics Theory of Probability and its Application. Theory ov Probability and Its Application, 38, 262295.

Embrechts, P., Kluppelberg, C., \& Mikosch, T. (1997). Modelling Extremal Events for Insurance and Finance. New York, NY: Springer.

Genest, C., Marceau, E., \& Mesfioui, M. (2003). Compound Poisson approximation for individual models with dependent risks. Insurance: Mathematics and Economics, 32, 73-85.

Grandell, J. (1997). Mixed Poisson Processes. London, UK: Chapman \& Hall.

Kaas, R., Goovaerts, M., Dhaene, J., \& Denuit, M. (2001). Modern Actuarial Risk Theory. Boston, USA: Kluwer Academic Publishers.

Kingman, J. F. C. (1993). Poisson Processes. Oxford: Clarendon Press.

Kling, B. M., \& Goovaerts, M. (1993). A note on compound generalized distributions. Scandinavian Actuarial Journal, 1, $60-72$.
Klugman, S., Panjer, H. H., \& Willmot, G. E. (1998). Loss Models: from Data to Decisions. New York, NY: John Wiley.

Landsman, Z., \& Sherris, M. (2001). Risk measures and insurance premium principles. Insurance: Mathematics and Economics, 29(1), 103-115.

Lundberg, F. (1932). Some supplementary research on the collective risk theory. Skandinavisk Aktuarietidskrift, 15, 137158 .

Mikosch, T. (2004). Non-Life Insurance Mathematics: An Introduction with Stochastic Processes. Berlin, Germany: Springer.

Minkowa, L. (2010). Insurance Risk Theory. Lecture Notes. from www.fmi.uni-sofia.bg

Panjer, H. H., \& Willmot, G. E. (1992). Insurance Risk Models. Schaumburg, Illinois: Society of Actuaries.

Ramasubramanian, S. (2005). Poisson process and insurance: an introduction. Prepared for a series of lectures given at a Refresher course in Applied Stochastic Processes, held at the Indian Statistical Institute, New Delhi, from http://www. math.iisc.ernet.in

Rolski, T., Schmidli, H., Schmidt, V., \& Teugels, J. (1999). Stochastic Processes for Insurance and Finance. New York, NY: Wiley and Sons.

Shari, A. H., \& Panjer, H. H. (1995). An improved recursion for the compound generalize Poisson distribution. Mitteilungen der Vereinigung Schweizerischer Versicherungsmathematiker, 1, 93-98.

Zlata Đurić je asistent na nastavnim predmetima Matematika u ekonomiji i Finansijska i aktuarska matematika, na Ekonomskom fakultetu Univerziteta u Kragujevcu. Ključno istraživačko interesovanje je primena matematičke aparature na ekonomsku problematiku, odnosno, finansijska matematika i modeli osiguranja. 


\title{
COLLECTIVE RISK MODEL IN NON-LIFE INSURANCE
}

\author{
Zlata Djuric \\ Faculty of Economics, University of Kragujevac, Kragujevac, Serbia
}

The operation of business insurance companies, based on assuming risks of different profiles, is accompanied by fluctuations in the business environment. The complexity of predicting a financial effect for claims in non-life insurance lies in the structure of insurers' liabilities, whose amount cannot be determined at the time of payment of the premium. By analyzing the key insurance processes, risk theory focuses on modeling claims as the financial consequences of unforeseen events. In addition, it provides the answer as to how much of a premium to charge in order to avoid bankruptcy, which makes it a complex and topical research area. The paper presents the main results of the collective risk model for the key business processes of nonlife insurance companies: the claim number process and the claim amount process. In risk theory, these are treated as stochastic processes, which offers a wide range of possibilities for the modeling and simulation of specific business problems.

Keywords: general insurance, risk theory, stochastic process, Poisson process, premium calculation principles

JEL Classification: C13, C43, C46 